\title{
Perilaku Prososial vs Kekerasan Sosial: Sebuah Tinjauan Pendidikan Islam
}

\author{
Ahmad Darmadji*
}

\begin{abstract}
This paper is formulated to make a brief outlook on social violence in the perspective of Islamic education view, Indonesian culture, and al-Qur'an. Based on this perspective, this paper will discuss the root of violence behavior, whether in recent time or in the past time. This paper will also discuss pro-social behavior developed by individual as well as by society, as it becomes a counter values to violence behavior. The values found through discussion will be then introduced in an education framework as a pathway in reframing social behavior that potentially leads to violence. This action is taken due to re-comphrehend and reduce such potential 'leads-to-violence' behavior. The discussion presented in this paper is expected to have an inspiration for the next researches.
\end{abstract}

Keywords: pro-social behavior, social violence, Islamic education.

* Disampaikan pada Seminar Nasional Pendidikan Islam di Gedung Prof. dr. Sardjito Kampus Terpadu UII, 1 Mei 2010.

** Staf Edukatif Program Studi Pendidikan Agama Islam Fakultas Ilmu Agama Islam UII dan Asesor BAN-PT

\section{A. Pendahuluan}

Dalam beberapa bulan terakhir ini, setidaknya terdapat dua kejadian besar yang mengusik kepedulian sosial kita bersama sebagai bangsa, yaitu insiden kekerasan di Bima, NTT, dan kerusuhan Lampung. Insiden di Bima merupakan gambaran dari konflik kepentingan yang melibatkan masalah ekonomi, dan politik kekuasaan karena melibatkan kepentingan korporasi/perusahaan besar, masyarakat adat, dan aparat pemerintah. Adapun dalam kasus di Lampung, masalah ekonomi, budaya, dan isu agama menjadi lokomotif utama pendorong kejadian yang menghancurkan jalinan dan kohesi sosial yang telah terbangun sejak lama. Bukan hanya fasilitas fisik yang rusak, korban jiwa pun tak terhindarkan dalam kejadian tersebut.

Dua peristiwa ini tidak bisa tidak membawa kembali memori kekerasan yang sejak masa reformasi seolah menjadi budaya laten di hampir seluruh wilayah di tanah air dan terjadi dengan beragam pemicu. Konflik berlatar belakang agama, sosial, politik, dan budaya yang demikian merata dan tinggi frekuensinya seolah membuat bangsa ini perlu bertanya lagi secara kritis, benarkah Bhineka Tunggal Ika memang benar-benar menjadi motto hidup yang mengakar pada kehidupan bangsa ataukah sekedar simbolisasi harapan kekuasaan semata.

Bagi umat Islam Indonesia, kekerasan sosial yang terus menghiasi kehidupan berbangsa juga menyimpan sejumlah permasalahan terkait dengan tanggung jawab ajaran Islam bagi kemanusiaan. Islam yang sedari awal digaungkan sebagai keselamatan dan diarahkan untuk membawa rahmat bagi seluruh alam, kadang gagal menjadi perekat dan pelindung keanekaragaman yang membingkainya menjadi harmoni. Bahkan terkadang, akibat ekstremisme, radikalisme, dan terorisme, Islam kerap menjadi kambing hitam dari kekerasan sosial yang terjadi. Kondisi ini menunjukkan pentingnya upaya menggali dan menerapkan nilai-nilai ajaran Islam yang mampu mengarahkan masyarakat dan umat Islam pada harmoni sosial yang berkeadilan, sehingga kekerasan sosial yang seolah menjadi bagian budaya bangsa dapat sedikit demi sedikit dieliminasi.

Tulisan singkat ini akan diformulasikan untuk melihat secara sekilas perihal kekerasan sosial dalam konteks Islam, Indonesia, dan tinjauan al-Qur'an untuk kemudian dikontraskan dengan perilaku sosial 
sebagai jawaban alternatif bagi masalah tersebut. Diharapkan kajian singkat dari tulisan ini akan mengilhami kajian lebih lanjut terkait kekerasan sosial dan solusinya dalam kerangka pendidikan agama Islam di Indonesia.

\section{B. Pembahasan \\ 1. Kekerasan Sosial: Konsep Dasar dan Pengalaman Sejarah di Indonesia}

Smead (2007) menyebutkan sejumlah bentuk dari kekerasan sosial (sosial violence) yang biasa terjadi dan terutama dikaitkan dalam sejarah Amerika Serikat, diantaranya yaitu kerusuhan massal (riots), pemogokan pekerja (labor strikes), dan pembantaian (lynching). Suryo (1997) juga melihat kerusuhan sebagai bagian dari kekerasan sosial merupakan faktor yang laten dalam sejarah hampir seluruh masyarakat. Perubahan-perubahan yang membawa krisis merupakan awal yang memungkinakn terjadinya berbagai kerusuhan (riot) maupun kekerasan (violence) sebagai artikulasi reaksi dan protes atas perubahan yang sedang berlangsung.

Dengan kerangka ini, tidak akan sulit untuk melihat akar kekerasan sosial dari sejarah panjang kehidupan bangsa Indonesia. Thohir (2008) misalnya menyebutkan bahwa sejak masa Ken Arok di Singasari hingga Amangkurat II di Mataram, tradisi kekerasan dalam politik kerajaan di Nusantara sudah terjadi. Sejarah kekerasan ini juga terus berlanjut hingga masa penjajahan Belanda dengan politik adu dombanya yang mengakibatkan konflik sosial semakin marak, baik berbasis perebutan kekuasaan antara anggota keluarga kerajaan, ataupun antara anggota keluarga kerajaan dengan rakyat. Politik diskriminasi ras yang membedakan antara bangsa Indonesia dengan bangsa Eropa maupun bangsa Asia lainnya merupakan salah satu pemicu yang menyebabkan konflik dan kekerasan muncul dan terus menerus bertahan. Tradisi kekerasan juga terus berlanjut hingga masa akhir Orde Lama, yang mengatasnamakan upaya menyelamatkan negara dari Gerakan 30 September.

Orde Baru yang menggantikan Orde Lama juga menunjukkan karakter penguasa yang dominan sehingga memunculkan beragam konflik (Aceh, Lampung, Timor-Timur, dan sebagainya) yang kesemuanya mengindikasikan tarikan kepentingan antara penguasa pusat dan masyarakat di daerah. Di akhir masa pemerintahan Orde Baru, fenomena kekerasan lokal juga nampak mengemuka mulai dari peristiwa 27 Juli 1996 di Jakarta, Situbondo 10 Oktober 1996, Tasikmalaya 26 Desember 1996, SanggauledoJanuari-Februari 1997, Rengasdengklok Februari 1997 (Suryo, 1997), dan sejumlah peristiwa lainnya termasuk yang paling sering disebut sebagai pemicu reformasi, yaitu peristiwa Mei 1998.

Fakta banyaknya kekerasan di tengah bangsa Indonesia yang mayoritas beragama Islam tentu menarik untuk dianalisa. Menurut Thohir (2009) setidaknya terdapat tiga pandangan yang menghubungkan agama dan kekerasan sosial. Pertama agama dan kekerasan sosial dilihat secara oposisi biner (binary opposition). Agama dalam kerangka ini pada dasarnya menolak kekerasan karena merupakan ekspresi dari penyimpangan agama. Agama diyakini hadir dalam rangka mengembangkan peradaban umat manusia dengan rahmatan lil alamin sebagai hasil akhir. Oleh karena itu, upaya mencapai tujuan tersebut selayaknya dilakukan dengan cara yang damai dan jauh dari kekerasan. Melalui kerangka pemikiran semacam ini, maka setiap kekerasan sosial merupakan penyelewengan atas makna agama itu sendiri, baik oleh karena kepentingan individu atau kelompok, dan bukan oleh kepentingan agama.

Pandangan kedua menjelaskan bahwa antara agama dan kekerasan sosial beroperasi di dalam ranah yang berbeda. Agama pada dasarnya berada dalam ruang sakral, sedangkan kekerasan sosial berada dalam ruang profan. Dengan kata lain, kekerasan sosial itu terjadi di luar wilayah keagamaan sehingga agama tidak bertanggung jawab atas kekerasan yang terjadi. Adapun pandangan ketiga melihat bahwa agama dan kekerasan sosial dapat saling bersinggungan dalam batas-batas tertentu, baik sebagai tanggapan atau strategi dalam menjawab kondisi yang ada. Kekerasan yang muncul dan diklaim dalam kerangka "amar ma' rûf nahî munkar" atau "jihad" dalam Islam dapat dikategorikan dalam kerangka ini.

Al-Quran antara lain menggunakan kata-kata yang berakar dari huruf fấ, sin dan dâl (fasad) untuk menggambarkan kerusakan sebagai ulah manusia. Derivasi kata ini dalam bentuk plural, yang mengindikasikan proses perusakan secara bersamasama oleh sekelompok manusia, juga banyak ditemukan. Diantaranya dalam al-Qur'an surat alBaqarah [2]: 27 (untuk mensifati kaum munafik Madinah), an-Nahl [16]: 88 (untuk mensifati kaum 
musyrik), ar-Ra'du [13]: 25 (untuk mensifati orangorang yang ingkar kepada Allah), asy-Syu'arâ [26]: 152 (untuk mensifati orang-orang yang melampaui batas), dan an-Naml [27]: 48 (untuk mensifati sekelompok kaum Tsamud di masa Nabi Shaleh as.).

Dalam al-Qur'an, perilaku kekerasan yang memakan korban manusia juga cukup sering disebutkan, baik dalam kerangka politik kekuasaan, agama, dan aspek lainnya. Pada Surat al-Baqarah [2] ayat 84, misalnya, Bani Israel diingatkan Allah dengan janji mereka kepada Allah SWT untuk tidak menumpahkan darah dan mengusir saudara sebangsa: dan (ingatlah), ketika Kami mengambil janji dari kamu (yaitu): kamu tidak akan menumpahkan darahmu (membunuh orang), dan kamu tidak akan mengusir dirimu (saudaramu sebangsa) dari kampung halamanmu, kemudian kamu berikrar (akan memenuhinya) sedang kamu mempersaksikannya.

Janji dengan Allah SWT (mîtsâq) ini memang pada akhirnya dikhianati oleh Bani Israel sebagaimana dijelaskan dalam ayat 85 yang mengikuti ayat di atas. Dua suku Yahudi di Madinah pada permulaan Hijrah, yaitu Bani Quraizhah yang bersekutu dengan suku Aus, dan Bani Nadhir yang bersekutu dengan orang-orang Khazraj merupakan gambaran tersebut. Antara suku Aus dan suku Khazraj sebelum Islam selalu terjadi persengketaan dan peperangan yang menyebabkan Bani Quraizhah membantu Aus dan Bani Nadhir membantu orangorang Khazraj. Sampai antara kedua suku Yahudi itupun terjadi peperangan dan tawan-menawan, karena membantu sekutunya.

Konflik dan kekerasan ini sangat ditekankan untuk dihindari karena pada dasarnya Bangsa Israel telah diselamatkan dari ujian besar (balâun 'adhîm) selama masa Fira'un. Fira'un digambarkan di dalam al-Quran sebagai pelaku kejahatan kemanusiaan dengan latar belakang politik dan kekuasaan. Demi menghalangi terwujudnya ramalan lahirnya seorang anak laki-laki yang akan menumbangkan kekuasaannya, setiap bayi laki-laki di zamannya dibunuh dan hanya menyisakan bayi perempuan. Dalam al-Qur'an Allah SWT berfirrman: Dan (ingatlah) ketika Kami selamatkan kamu dari (Fir'aun) dan pengikut-pengikutnya; mereka menimpakan kepadamu siksaan yang seberatberatnya, mereka menyembelih anak-anakmu yang laki-laki dan membiarkan hidup anak-anakmu yang perempuan. dan pada yang demikian itu terdapat cobaan-cobaan yang besar dari Tuhanmu (QS. .

Gambaran kekejaman Firaun juga terdapat dalam sejumlah ayat dalam al-Qur'an yang dirangkai dengan peringatan bagi Bani Israel untuk mensyukuri kebebasan mereka dari bencana tersebut (lihat QS. al-A'râf [7]: 141, Ibrahim [14]: 6). Selain Fira'un dengan kekuasaannya, perilaku merusak juga diindikasikan al-Qur'an dilakukan bangsa-bangsa lain, sebagaimana tergambar dalam surat al-Fajr [89] rangkaian ayat 7-14. Rangkaian ayat ini menggambarkan perilaku rusak yang dilakukan bangsa-bangsa seperti kaum 'Ād yaitu penduduk daerah Iram, kaum Tsamud, dan Fira'un dengan karakter sewenang-wenang dan merusak, sebagaimana dijelaskan dalam ayat 11-12: (yaitu) yang berbuat sewenang-wenang dalam negeri, lalu mereka berbuat banyak kerusakan dalam negeri itu.

Karena itulah, Allah swt. dalam al-Qur'an juga mengisyaratkan larangan keras untuk perbuatan merusak, membunuh, dan sebagainya. Larangan melakukan kerusakan di muka bumi antara lain disebutkan dalam QS. al-A'râf [7]: 56 dan 84 dalam konteks kaum Madyan di masa Nabi Syu'aib as (dan janganlah kamu membuat kerusakan di muka bumi, sesudah (Allah) memperbaikinya) dengan menggunakan bentuk (shighah) larangan 'lâ tufsidû. Al-Qur'an juga menggunakan bentuk larangan ' $w a$ lâ ta'sau fil ardhi mufsidîn' sebagaimana terlihat dalam surat al-Baqarah [2]: 60 (berkaitan dengan Bani Israel), al-A'râf [7]: 74 (berkaitan dengan kaum nabi Shaleh as.), Hûd [11]:85, asy-Syu'arâ' [26]:183, dan al-'Ankabût [29]: 36 (ketiganya berkaitan dengan kaum Nabi Syua'ib as.).

\section{Perilaku Prososial: Pengertian, Aspek, Ciri, dan Faktor yang Mempengaruhinya}

Perilaku prososial menurut Baron dan Bryne (2007) adalah suatu tindakan menolong yang menguntungkan orang lain tanpa harus menyediakan suatu keuntungan langsung pada individu yang melakukan tindakan tersebut, dan bahkan mungkin mengandung suatu resiko bagi individu yang menolong. Staub (dalam Basti, 2007) mendefinisikan perilaku prososial sebagai suatu perilaku yang memiliki konsekuensi sosial positif secara fisik maupun psikologis, dilakukan secara sukarela dan menguntungkan orang lain. 
Sears, dkk. (2003) menyebutkan bahwa perilaku prososial mencakup kategori lebih luas, meliputi segala bentuk tindakan yang dilakukan atau direncanakan untuk menolong orang lain tanpa memperdulikan motif si penolong. Wrightsman dan Deaux (dalam Basti, 2007) mendefinisikan perilaku prososial sebagai perilaku seseorang yang mempunyai konsekuensi sosial positif yang ditujukan bagi kesejahteraan orang lain secara fisik maupun psikologis dan perilaku tersebut merupakan perilaku yang lebih banyak memberi keuntungan pada orang lain daripada dirinya sendiri.

Menurut Shaffer (2000) perilaku prososial adalah segala tindakan yang menguntungkan orang lain, seperti berbagi dengan seseorang yang kurang beruntung dari dirinya, menghibur, menyelamatkan orang yang tertekan, bekerja sama dengan seseorang atau membantu mencapai objektif, atau bahkan hanya membuat orang merasa senang dengan memujinya pada keahliannya. Perilaku prososial adalah suatu tindakan yang ditujukan untuk memberi manfaat bagi orang lain (Kenrick dkk. 2006).

Perilaku prososial menurut William (dalam Syafriman dan Yapsir, 2000) adalah tingkah laku seseorang yang bermaksud mengubah keadaan psikis atau fisik penerima sedemikian rupa, sehingga si penolong akan merasa bahwa si penerima menjadi lebih sejahtera atau puas secara material ataupun psikologis. Pengertian tersebut menekankan pada maksud dari perilaku untuk menciptakan kesejahteraan fisik maupun psikis. Selain itu, menurut Baumeister dan Bushman (2008) Perilaku prososial didefinisikan sebagai melakukan sesuatu yang baik bagi orang lain atau masyarakat secara keseluruhan.

Menurut Bartal (dalam Syafriman dan Yapsir, 2000) perilaku prososial adalah tingkah laku yang menimbulkan konsekuensi positif bagi kesejahteraan fisik maupun psikis orang lain. Perilaku tersebut meliputi pengertian yang luas antara lain perilaku menolong, bekerja sama, menyumbang dan membagi, serta mempertimbangkan kesejahteraan orang lain. Berdasarkan beberapa batasan pengertian perilaku prososial di atas dapat disimpulkan bahwa perilaku prososial adalah segala bentuk perilaku yang ditujukan bagi kepentingan orang lain dengan tindakan nyata, sukarela, dan memiliki akibat positif dari tindakannya tersebut.

Menurut Mussen, dkk. (dalam Basti, 2007) beberapa aspek dari perilaku prososial adalah:

a. Membagi. Membagi didefinisikan ketika individu yang memiliki kecukupan untuk saling membagi kelebihannya tersebut baik materi maupun ilmu pengetahuan kepada orang lain.

b. Bekerja sama. Bekerja sama merupakan suatu bentuk perilaku yang sengaja dilakukan oleh sekelompok orang maupun organisasi demi terwujudnya suatu cita-cita yang diinginkan bersama.

c. Menolong. Menolong merupakan suatu tindakan sukarela tanpa mempedulikan untung maupun rugi dari tindakan menolong dan tanpa mengharapkan imbalan apa-apa dari orang yang ditolong.

d. Kejujuran. Kejujuran adalah suatu bentuk perilaku yang ditujukan dengan perkataan yang sesuai dengan keadaan dan tidak menambahkan atau mengurangi kenyataan yang ada.

e. Dermawan. Tindakan dermawan adalah suatu perilaku yang menunjukkan rasa kemanusiaan dengan cara memberikan sebagian hartanya kepada orang lain yang membutuhkan.

f. Mempertimbangkan hak dan kewajiban orang lain. Hak dan kewajiban merupakan hak asasi setiap manusia. Seorang individu yang memiliki sikap yang demikian ditunjukkan dengan cara menghargai hak-hak orang lain sebelum meminta kewajibannya terlebih dahulu.

Menurut teori Carlo dan Randall (dalam Gunawan, 2007), aspek-aspek perilaku prososial adalah:

a. Altruistic prosocial behavior, yaitu motivasi membantuoranglainterutamayangberhubungan dengan kebutuhan dan kesejahteraan orang lain, sering kali disebabkan oleh respon-respon simpati dan diinternalisasikan ke dalam normanorma atau prinsip-prinsip yang tetap dengan membantu orang lain.

b. Compliant prosocial behavior, yaitu membantu orang lain karena dimintai pertolongan baik verbal maupun non verbal.

c. Emotional prosocial behavior, yaitu membantu orang lain karena disebabkan perasaan emosi berdasarkan situasi yang terjadi.

d. Public prosocial behavior, yaitu perilaku menolong orang lain yang dilakukan di depan orang-orang setidaknya dengan suatu tujuan untuk memperolah pengakuan dan rasa hormat dari orang lain (orang tua, teman sebaya) dan meningkatkan harga diri. 
e. Anonnymous prosocial behavior, yaitu menolong yang dilakukan tanpa sepengetahuan orang yang ditolong.

f. Dire prosocial behavior, yaitu menolong orang yang sedang dalam keadaan krisis atau darurat.

Aspek-aspek perilaku prososial menurut Sampson (dalam Riyasari, 2004) adalah:

a. Peduli, yaitu mampu memberi perhatian dan membantu orang lain dengan cara meringankan beban fisik atau psikologis yang sedang dirasakan orang tersebut.

b. Bekerjasama, yaitu mencapai tujuan melakukan pekerjaan atau kegiatan secara bersama berdasar kesepakatan untuk mencapai tujuan bersama pula.

c. Berbagi rasa, yaitu kesediaan untuk ikut merasakan apa yang dirasakan oleh orang lain.

d. Memberi atau menyumbang, yaitu berlaku murah hati kepada orang lain

e. Memberi fasilitas untuk kesejahteraan orang lain, yaitu peduli terhadap permasalahan orang lain.

Perilaku prososial sering disamakan dengan perilaku altruistik, karena perbedaannya memang sangat tipis. Perbedaan keduanya lebih ditekankan pada orientasi tujuan perilaku (Baron \& Bryne, 2007). Perilaku altruistik lebih diarahkan pada kepentingan orang lain dan tidak mengharapkan adanya balasan. Perilaku tersebut dimotivasi oleh dorongan dalam diri individu untuk membuat orang lain merasa lebih baik. Sementara perilaku prososial lebih dikaitkan dengan internal reward yang berupa perasaan puas dan bahagia apabila dapat menolong orang lain, yang berarti membebaskan diri dari perasaan bersalah dan berdosa atas penderitaan orang lain. Namun demikian, baik perilaku prososial maupun perilaku altruistik keduanya mengandung faktor kerelaan dan menguntungkan orang lain.

Perilaku prososial bercirikan segala tindakan baik yang direncanakan secara formal dan informal atau yang bersifat spontan, sedangkan ciri yang bersifat frekuensi dibagi tiga bentuk mendasar yaitu formal planned helping, informal planned helping, dan spontaneous or unplanned helping (Amato dalam Pohan \& Vivi, 2006). Menolong orang yang direncanakan (planned helping) berarti bahwa orang akan berpikir lebih jauh terhadap pertolongan yang dia berikan kepada orang lain; dan menolong spontan (spontaneous helping) adalah bantuan yang diberikan seketika. Menolong secara formal (formal helping) adalah bentuk pertolongan yang diberikan kepada sebuah organisasi formal, sementara menolong secara informal (informal helping) berarti pertolongan yang diberikan kepada teman, keluarga, termasuk kepada orang yang tidak dikenal.

Munculnya perilaku prososial seseorang merupakan hasil interaksi yang kompleks antara beberapa faktor yang mempengaruhinya, baik faktor internal maupun faktor eksternal termasuk di dalamnya adalah faktor budaya dan peran gender. Basti (2007) menyatakan bahwa dari pendapat beberapa ahli, beberapa faktor internal yang mempengaruhi perilaku prososial yaitu: (1) karakteristik kepribadian; (2) suasana hati; (3) religiusitas; (4) pertimbangan untung-rugi; (5) kemampuan yang dimiliki; (6) keuntungan pribadi; (7) nilai dan norma-norma pribadi; (8) empati; (9) jenis kelamin. Adapun yang termasuk faktor eksternal adalah: (1) budaya; (2) keluarga; (3) karakteristik orang yang membutuhkan pertolongan; (4) karakteristik situasional (5) faktor Peran gender; dan (6) etnis.

Sedangkan menurut Syafriman dan Yapsir (2000), perilaku prososial dipengaruhi oleh berbagai faktor yaitu, (1) faktor situasional, seperti kehadiran orang lain, faktor lingkungan dan kebisingan, faktor tanggung jawab, faktor kemampuan yang dimiliki, faktor desakan waktu, latar belakang keluarga, (2) faktor internal seperti faktor pertimbangan untung rugi, faktor nilai-nilai pribadi, faktor empati, suasana hati (mood), faktor sifat, faktor tanggung jawab, faktor agama, tahapan moral, orientasi seksual, jenis kelamin, (3) faktor penerima bantuan yang meliputi karakteristik orang yang memerlukan pertolongan, kesamaan penolong dengan yang memerlukan pertolongan, asal daerah, daya tarik fisik, (4) faktor budaya meliputi nilai dan norma yang berlaku pada suatu masyarakat khususnya norma tanggung jawab sosial, norma timbal balik dan norma keadilan.

Secara umum, menurut Myers (dalam Pohan \& Vivi, 2006) perilaku prososial dipengaruhi oleh dua faktor, yaitu faktor situasional dan faktor personal. Faktor situasional melipti karakteristik dari orang yang membutuhkan pertolongan, jumlah serta kehadiran bystander serta tekanan waktu. Faktor personal yang mempengaruhi perilaku prososial adalah emosi, perasaan, empati, traittrait kepribadian, dan mood, selain itu juga normanorma. 
Sedangkan indikator atau ciri dari tindakan prososial adalah tindakan berakhir pada dirinya (secara individu) dan tidak menutup menuntut keuntungan secara sukarela menghasilkan kebaikan. Tindakan atau perilaku prososial disadari oleh minat pribadi, bukan didasari oleh adanya pengorbanan diri, seperti perilaku altruistik. Karena kadangkadang juga lebih lanjut oleh Staub mengatakan bahwa tujuan perilaku prososial adalah untuk memperoleh reward seperti perasaan puas, bahagia, dapat menolong orang lain.

Ajaran Islam sebagaimana ditegaskan alQur'an banyak sekali menyinggung masalah prososial ini. Gambaran yang paling jelas nampak dari pujian Allah SWT terhadap kelompok Anshar yang demikian solider dalam memberikan bantuan kepada kelompok Muhajirin di masa awal hijrah ke Madinah. Kelompok Anshar digambarkan merupakan komunitas beriman yang merelakan banyak pemberian dan juga mengutamakan kelompok Muhajirin yang baru datang. Firman Allah SWT: dan orang-orang yang telah menempati kota Madinah dan telah beriman (Anshor) sebelum (kedatangan) mereka (Muhajirin), mereka (Anshor) 'mencintai' orang yang berhijrah kepada mereka (Muhajirin). dan mereka (Anshor) tiada menaruh keinginan dalam hati mereka terhadap apa-apa yang diberikan kepada mereka (Muhajirin); dan mereka mengutamakan (orang-orang muhajirin), atas diri mereka sendiri, Sekalipun mereka dalam kesusahan. dan siapa yang dipelihara dari kekikiran dirinya, mereka itulah orang orang yang beruntung (QS. .

Selain itu, al-Qur'an juga menggambarkan keikhlasan dan kebersahajaan keluarga Sayyidina Ali kw. dalam memberikan makanan yang jumlahnya terbatas ('alâ hubbihîl) kepada orang miskin, yatim piatu, dan orang yang ditawan. Dalam al-Qur'an Allah mengisahkan: dan mereka memberikan makanan yang disukainya kepada orang miskin, anak yatim dan orang yang ditawan (QS.

Kemampuan memberikan sesuatu yang sangat dicintai demi kebaikan demi kebaikan orang lain atau masyarakat juga menjadi salah satu pokok kebajikan sebagaimana dijelaskan dalam al-Qur'an surat alBaqarah [2]: 177, yaitu: dan memberikan harta yang dicintainya kepada kerabatnya, anak-anak yatim, orang-orang miskin, musafir (yang memerlukan pertolongan) dan orang-orang yang meminta-minta; dan (memerdekakan) hamba sahaya. Juga surat Ali Imran [3]: 92, yaitu: amu sekali-kali tidak sampai kepada kebajikan (yang sempurna), sebelum kamu menafkahkan sehahagian harta yang kamu cintai.

Kemampuan memberi sebagian rizki juga menjadi bagian dari sifat orang bertakwa yang dijelaskan di bagian awal surat al-Baqarah: (orang yang bertakwa yaitu) mereka yang beriman kepada yang ghaib, yangmendirikan shalat, danmenafkahkan sebahagian rizki yang Kami anugerahkan kepada mereka (QS. al-Baqarah [2]: 3). Karakter pemurah juga menjadi watak pribadi bertakwa sebagaimana diungkapkan QS Ali Imran[3]:134: (yaitu) orangorang yang menafkahkan (hartanya), baik di waktu lapang maupun sempit, dan orang-orang yang menahan amarahnya dan mema'afkan (kesalahan) orang. Allah menyukai orang-orang yang berbuat kebajikan.

Puncak dari ajaran prososial dalam Islam antara lain juga tampak dari perintah untuk membangun komunitas yang aktif bekerjasama dalam kebajikan dan takwa; Dan tolong-menolonglah kamu dalam (mengerjakan) kebajikan dan takwa, dan jangan tolong-menolongdalamberbuatdosadanpelanggaran (QS. al-Mâ'idah [5]: 2). Perintah membangun komunitas yang cenderung pada kebaikan, Dan hendaklah ada di antara kamu segolongan umat yang menyeru kepada kebajikan, menyuruh kepada yang ma'ruf dan mencegah dari yang munkar (QS. Ali Imran [3]: 104), yang kesemuanya merupakan implementasi misi profetik membawa kedamaian bagi seluruh alam, Dan tiadalah Kami mengutus kamu, melainkan untuk (menjadi) rahmat bagi semesta alam (QS. al-Anbiyấ, [21]: 107) dan menciptakan masyarakat yang sejahtera lahir batin, (negerimu) adalah negeri yang baik dan (Tuhanmu) adalah Tuhan Yang Maha Pengampun (QS. Sabâ' [34]: 15).

\section{Penutup}

Perilaku prososial diharapkan selalu mewarnai kehidupan kita sehari-hari. Untuk mewujudkan perilaku prososial diperlukan apa yang disebut dengan empati. Menurut Cohen (dalam Sampson, 1976) empati adalah kemampuan seseorang untuk ikut merasakan perasaan atau pengalaman orang lain. Seseorang akan bereaksi secara empatik atau tidak, tergantung pada nilai dan norma yang dikukuhinya. Orang yang memiliki orientasi nilai pada kesejahteraan orang lain akan lebih cepat reaksi empatinya terhadap penderitaan yang dialami orang 
lain, dibandingkan dengan mereka yang kurang memikirkan kesejahteraan orang lain. Sejak awal perkembangan hidup manusia, empati sudah dapat diusahakan pembentukannya. Orang tua (guru) mempunyai tanggung jawab besar dalam mendidik anak-anaknya. Sebagai khalifah Allah di bumi manusia wajib mendidik dan mengasuh anak sesuai dengan tuntunan-Nya. Sabda nabi Muhammad SAW, anak menjadi Nasrani, Yahudi, ataupun Majusi tergantung pada orang tuanya.

Orang tua atau guru yang mengasuh anak dengan menggunakan penjelasan dan diskusi serta pertimbangan agar anak dapat mengerti mengapa ia diharapkan berkelakuan tertentu merupakan pola asuhyangmenunjang terwujudnya perilaku prososial. Anak diberi kesempatan untuk mengekspresikan ide-idenya, toleran, dan bersifat terbuka. Apabila orang tua atau guru selalu memberikan penjelasan tentang konsekuensi suatu tindakan terhadap orang lain, mengantisipasi kejadian-kejadian tertentu dan memprediksi akibat-akibat tindakan orang lain, anak didorong untuk belajar alih peran (role taking) dan merespon secara empatik.

Dengan adanya patokan-patokan yang jelas dan peluang untuk berlatih alih peran, maka anak akan mengerti suatu respon atau tindakan yang efektif sehingga tidak menduga-duga apa yang sebaiknya dilakukan. Yang perlu diperhatikan bahwa anak berperilaku mempunyai kecenderungan untuk meniru dan terutama perilaku orang tua atau guru. Sehingga orang tua atau guru harus memberikan contoh yang mencerminkan perilaku prososial pula.

Banyak kasus kekerasan yang kita baca di media massa, baik cetak maupun elektronik yang dilakukan oleh orang tua atau guru yang dilakukan pada anak, yang seharusnya orang tua atau guru menjadi contoh pada anaknya. Hal ini sejalan dengan konsep teori modelling (Bandura, 1971), bahwa perilaku orang tua atau guru dapat menjadi sebuah model dalam proses meniru atau mengimitasi perilaku yang ditampilkan.

\section{Daftar Pustaka}

Andaritidya, A. 2007. Hubungan Antara Perilaku Prososial Dengan Kebermaknaan Hidup Pada Mahasiswa. Skripsi tidak dipublikasikan. Yogyakarta: Fakultas Psikologi dan Ilmu Soial Budaya, Universitas Islam Indonesia.
Baron, R.A., Byrne, D. 2003. Psikologi Sosial Edisi Kesepuluh. Jakarta: Erlangga.

Baron, R.A., Byrne, D., Branscombe, N.R. 2007. Mastering Social Pyschology. United States of America: Pearson Education, Inc.

Basti. 2007. 'Perilaku Prososial Etnis Jawa dan Etnis Cina'. Jurnal Psikologika 23/12 Januari, hal 57-68.

Bushman, B.J., Baumeister, R.F. 2008. Social Psychology \& Human Nature. United States of America: Thomson Higher Education.

Clarke, D. 2003. Pro-Social and Anti-Social Behaviour. New York: Routledge. E-book.

Gunawan,A. N.2007.Hubungan Antara Spiritualitas Dengan Perilaku Prososial Pada Relawan Gempa Bumi. Skripsi tidak dipublikaksikan. Yogyakarta: Fakultas Psikologi, Universitas Islam Indonesia.

Himmah, E. F. 2002. Pengaruh Kesesakan Terhadap Perilaku Prososial Pada Remaja Di Pemukiman Padat. Skripsi tidak dipublikasikan. Malang: Fakultas Psikologi, Universitas Muhammadiyah Malang. Available at http://www.digilib. unikom.ac.id

Kenrick, D.T., Neuberg, S.L., Cialdini, B.R. 2007. Social Psychology Goals In Interaction Fourth Edition. United States of America: Person Education.

Pohan, V. R \& Oscar. 2006. 'Perbedaan Perilaku Prososial Berdasarkan Orientasi Peran Jenis'. Jurnal Psikologika Nomor 22 Volume XI, Juli, hal 129- 136.

Riyasari, S.D. 2004. Hubungan Antara Kemampuan Berempati Dengan Perilaku Prososial. Skripsi tidak dipublikasikan. Yogyakarta: Fakultas Psikologi, Universitas Islam Indonesia.

Sears, D.O. 2009. Psikologi Sosial Edisi Kedua Belas. Jakarta: Kencana.

Shaffer. R.D. 1994. Social and Personality Development Third Edition. United States of America: Brooks/Cole.

Situmeang, Rosinta. 2004. Pengaruh Tempat Tinggal Terhadap Perilaku Prososial Dalam Pengelolaan Lingkungan Hidup. Abstrak. Program Pasca Sarjana, Universitas Sumatera Utara. Available at http://www.digilib.usu.ac.id 
Smead, H. (2007), Types of Social Violence. Diunduh dari http://www.howardsmead.com/ typesofsocialviolence.htm pada 28 April 2010.

Suryo, D., 1997, Kerusuhan Lokal dalam Perspektif Sejarah, Ulumul Quran No.5 VII/1997.

Syafirman \& Wirawan, Y. Gandi. 2000. Perbedaan Orientasi Nilai Dan Perilaku Prososial Antara Suku Bangsa Melayu Dan Suku Bangsa Tionghoa. Available at www.depsos.go.id

Lange, P.A., De Bruin, E.M., Otten, W., Joiremen, J.A. 1997. Development of Prosocial, Individualistic, and Competitive Orientations: Theory and Preliminary Evidence. Journal of Personality and Social Psychology, 73 (4), 733 746.

Thohir, M. (2008) Kekerasan Sosial dalam Kehidupan Masyarakat Indonesia: Suatu Pendekatan Sosial Budaya. Pidato Pengukuhan disampaikan pada Upacara Penerimaan Jabatan
Guru Besar dalam Ilmu Antropologi Budaya pada Fakultas Sastra Universitas Diponegoro Semarang, 12 Januari 2008. Diunduh dari laman situs http://eprints.undip.ac.id/302/1/ mudjahirin_tohir.pdf pada 29 April 2010.

(2009) Peran Pemimpin Nonformal dalam Kaitannya dengan Kekerasan Sosial dan Terorisme di Indonesia. Diunduh dari laman situs http://staff.undip.ac.id/sastra/ mudjahirin/2009/03/04/kekerasan-sosial/ pada 29 April 2010.

Yanti, D. 2005. Ketrampilan Sosial Pada Anak Menengah Akhir Yang Mengalami Gangguan Perilaku. Skripsi. Sumatera Utara: Program Studi Fakultas Psikologi, Fakultas Kedokteran, Universitas Sumatera Utara. 